\title{
Morphology of the Gonads of Cricosaura typica (Sauria: Xantusiidae)
}

\author{
Ana Sanz Ochotorena*, Luis M. Díaz**, Robert Murphy***, Carlos Domínguez**** \\ *Animal and Human Biology Department. Biology Faculty. University of Havana. Calle 25 \#455, \\ Vedado. CP 10400. Ciudad de la Habana, Cuba. \\ ** National Museum of Natural Sciences. Plaza de Armas y Oficios. CP 10600. Ciudad de La \\ Habana. Cuba \\ *** Centre for Biodiversity \& Conservation Biology. Royal Ontario Museum 100 Queen’ s Park, \\ Toronto, Ontario, Canada \\ ****Anatomy Pathology Deparment. Hermanos Ameijeiras Hospital. San Lázaro y Belascoaín. CP \\ 10600. Ciudad de La Habana. Cuba.
}

Cricosaura typica (Gundlach \& Peters, 1863), is the only Xantusid lizard of the Antilles and it belongs to a very old lineage [2]. The distribution of this species is restricted to some localities from Santiago de Cuba to Granma provinces of the Island of Cuba [4]. Also, the kariotype and DNA of C. typica shows that this lizard seems to be the basal clado inside the Xantusiidae Family, which transforms it into one of the oldest families in lizards of the world [3].

The singular reproduction way is another of its primitive characters. Without a doubt any, Cricosaura typica is not only an alive fossil for its distribution so reduced and loss of its habitat if not for the ignorance that exists about its biology.

The aim of the present work was to describe the morphology of ovaries and testis of this lizard. Dissection of three females and three males which died in the field in March of the year 2002 was carried out. The samples were weighed and measured and immediately their gonads and conduts were fixed in two differents solutions: Bouin's liquid and 3.2\% glutaraldehyde in $0.1 \mathrm{M}$ sodium cacodylate $\mathrm{pH} 7.3$, respectively. In the laboratory the gonads underwent the microscopic techniques. The histological cuts were stained with Hematoxilin-Eosin and Mallory. The longitude of the head of the sperm and the diameter of the oocytes were measured using the Motic Images System. The ultrathin cuts were observed in Transmisión JEOL'S Microscope 2000 [6].

The males present two ovoid testicles, the left one heigher than the right. The testicles showed a very thin and transparent tunica albuginea. Sexual cells were appreciated in diverse development degrees from the basal membrane toward the lumen in the seminiferous tubules what is typical of a radial spermatogenesis [1]. The great quantity of spermatozoa in the lumen of the seminiferous tubules and in the epididymis, indicated that they were adults and in full reproductive phase. The head of the spermatozoa was small and sharpened form.

The females also showed signs of sexual maturity. The ovaries were small, and presented previtellogenic follicles in the right ovary as well as in the left one and two vitellogenic follicles at least in the studied females. The previtellogenic oocytes presented a big nucleus with a great number of nucleoli [4]. The morphometric characteristic of the oocytes was also described. Chromosomes lampbrush were observed by TEM. The granular layer of the follicles differed of that found for other lizards of the Orden Squamata; different cellular types were not appreciated. 
Although the gonads of C. typica presented similarities with other reptiles they have peculiar characteristics. Male and female were in reproductive phase even in March, probably because at the East of Cuba in that time the weather is usually very warm.

- [1] Fox, W: Urogenital system of reptiles. In Gans, C. and T.S. Parsons (Eds): Biology of the reptilian morphology. Acad. Press. (6) 1-157 (1987)

$\circ$ [2] Hass, CA. and S. B. Hedges: Kariotype of the Cuban lizard Cricosaura typica and its implications for xantusiids phylogeny. Copeia (2): 563-566 (1992)

$\circ$ [3] Hedges, S. B. et al: Phylogenetic relationships and biogeography of xantusiids lizards inferred from mitocondrial DNA sequences. Mol Biol. Evol 8: 767-780 (1991)

- [4] Palmer, B. M. et al: Reproductive Anatomy and Physiology (In Reptiles) 54-87 (1998)

- [5] Fong, A. et al: Natural history of Cricosaura typica (Sauria:Xantusiidae) in Cuba. J. Carib. Sci 35 (1-2) 148-150: 1999.

○ [6] Reimer, L: Transmission Electron Micrsocopy: Physics of Image Formation and Microanalysis. (Springer Series in Optical Sciences. Springer Verlag. 608p Vol 36 (1997)

$\circ$ [7] The aid of Dr. Dave Morafka in support this research is gratefully acknowledged

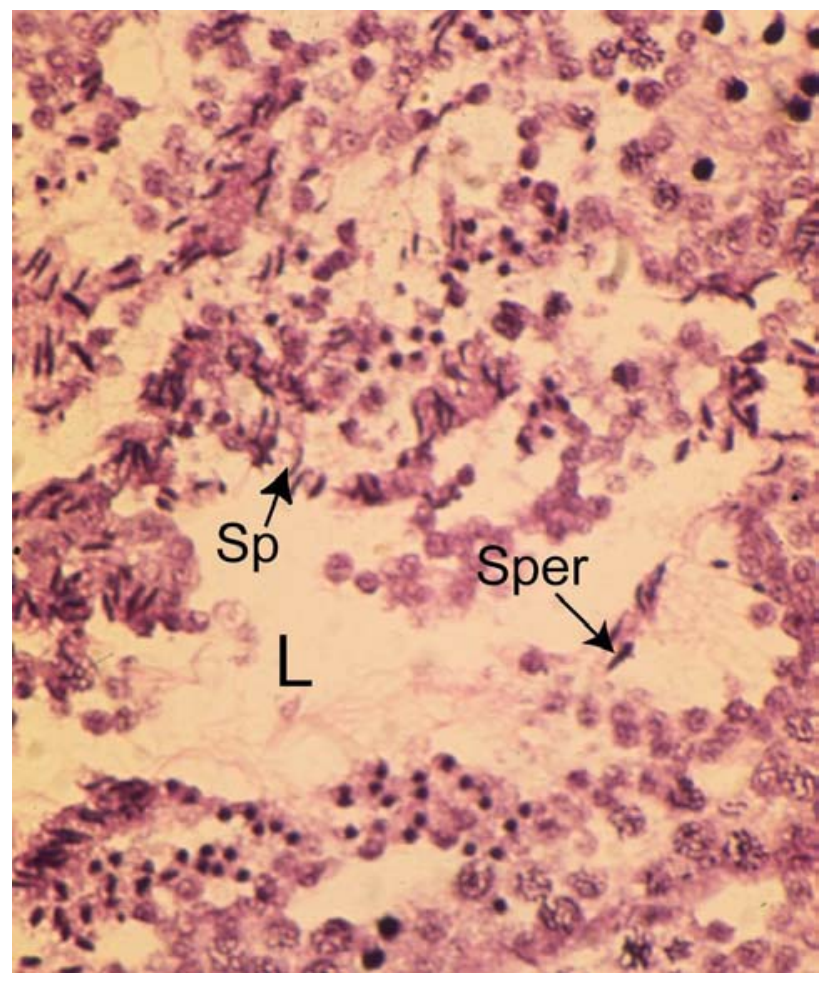

FIG. 1. Spermatogenetic cells in $C$. typica $(\mathrm{Sp}=$ spermatid, $\mathrm{Sper}=$ spermatozoa, $\mathrm{L}=$ lumen). Hematoxilin-Eosine 400X. 